\title{
Royal Society disputes value of carbon sinks
}

David Adam, London

Britain's Royal Society is pouring cold water on the idea that 'carbon sinks' of forest and farmland could soak up enough carbon dioxide to help industrialized nations meet their long-term emissions targets for reducing greenhouse gases.

Improvements in sink management could see more carbon dioxide sequestered, a report from the society says. But it adds that this would be a short-term, one-off benefit that should not be considered as a long-term alternative to cutting emissions.

The Royal Society's verdict comes as negotiators gather in Bonn, Germany, for the next round of climate-change talks, due to start on 16 July.

A previous round of talks last year in The Hague broke down after European negotiators rejected calls from the United States, Japan, Canada and Australia for a bigger role for carbon sinks.

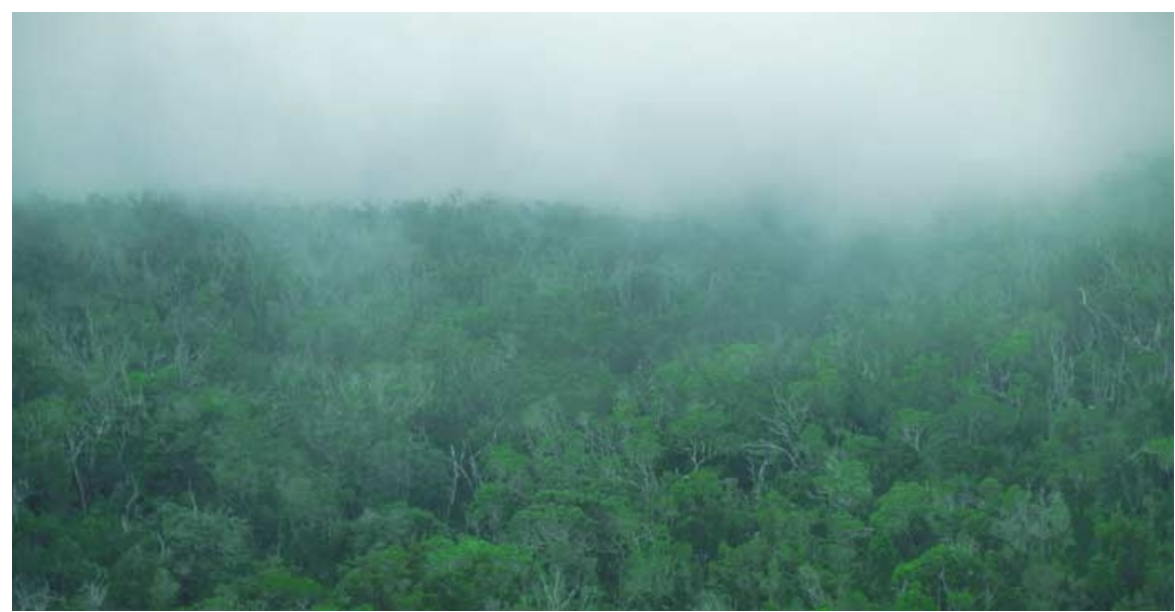

Sinking feeling: forest management may have a limited effect in reducing the greenhouse-gas mix.

This time round, the Europeans may offer concessions on carbon sinks in a bid to keep the Kyoto Protocol alive in the wake of

\section{Battle to save beleaguered beluga}

\section{Sally Goodman, Paris}

Police, researchers and fishery managers are to step up their battle to rescue the sturgeons of the Caspian Sea, whose famous eggs account for $90 \%$ of the world's caviar.

The illegal harvest of the fish and their valuable eggs - which is thought to exceed the legal catch by an order of magnitude is depleting supplies of the delicacy.

But conservationists say that the smart use of DNA markers to locate the precise

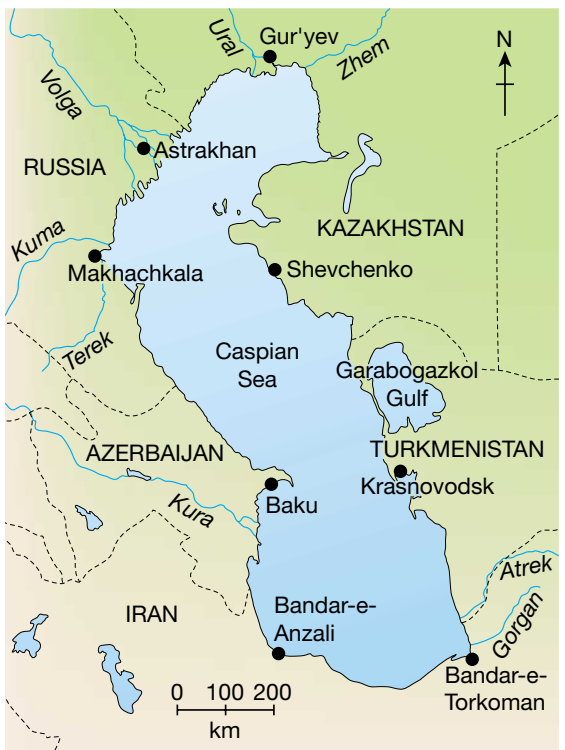

Nowhere to hide: an illegal trade in caviar is threatening sturgeons in the Caspian Sea. origins of illegally traded caviar could improve policing and allow the sturgeons, including the beluga (Huso huso), to survive.

Last month Russia, Azerbaijan and Kazakhstan - three of the five Caspian Sea states - agreed on a new 12-month action plan to save the sturgeons, at a Paris meeting of the Convention on International Trade in Endangered Species (CITES). Turkmenistan is expected to adhere to the agreement, and CITES declared the fifth state, Iran, exempt because of the quality of its existing sturgeon-management programme.

The states agreed to collaborate with CITES and Interpol, the international network of police. Scientists in the region plan to develop a comprehensive set of the DNA markers that locate the precise source of caviar. The states also pledged to negotiate details of a sustainability programme.

The agreement calls for the cancellation of the autumn 2001 caviar harvest, with export only permitted of fish eggs left over from the spring, on pain of a total caviarexport ban next year. But observers question whether this will halt illegal harvesting.

Sabri Zain, an official at the World Wildlife Fund, warns that any ban on legal exports would weaken pressure on governments to clamp down on illegal fishing and trading. Zain wants to see a labelling system to identify legal caviar.

Scientists and fishery experts meet this week at Oshkosh, Wisconsin, to discuss ways of securing the fish's future.

http://www.cites.org
US President George W. Bush's decision to abandon it. But the Royal Society report inconveniently challenges the potential usefulness of carbon sinks as a means of addressing the climate-change problem.

"Land carbon sinks may help to reduce greenhouse-gas levels in the atmosphere in the short term, but the amounts of carbon dioxide that can be stored are small compared to emissions from the burning of fossil fuels," says David Read, a plant scientist at the University of Sheffield, who chaired the working group that prepared the report.

Terrestrial vegetation and soil currently absorb about $40 \%$ of global carbon-dioxide emissions from human activities. The report agrees that changes to agricultural and forestry practices, such as planting fastgrowing 'biofuel' crops and slowing deforestation, could increase this capacity. But it argues that carbon sinks are not a long-term solution because they will quickly become saturated and unable to soak up any more carbon dioxide.

"Managed land sinks could potentially meet $25 \%$ of the reductions in carbon dioxide projected to be required globally by 2050," the report says. "However, this would require considerable political will and there is little potential for increasing the land carbon sink thereafter."

The report adds that it is difficult to assess even the short-term usefulness of sinks because of uncertainties in monitoring techniques and suggestions that some sinks could even switch to releasing their stored carbon dioxide in future.

Furthermore, the report warns that some practices designed to boost the capacity of carbon sinks, such as large-scale use of nitrogen-based fertilizers, could actually increase climate change by releasing other greenhouse gases, including methane and nitrous oxide.

http://www.royalsoc.ac.uk/policy/csink_ann.pdf 